\title{
The trace element composition of a range of modern and Archean microbial carbonates
}

\author{
MARTIN*, A. N. ${ }^{1}$, UnRUH, C.S., ${ }^{1}$ LAZAROV, M. ${ }^{1}$, \\ MARKOWSKA, M. ${ }^{2,3}$, JUNGINGER, A. ${ }^{2}$, BiSCHOFF, K. ${ }^{4}$, \\ ChIVAS, A.R ${ }^{5}$, WeYer, S. ${ }^{1}$ \\ ${ }^{1}$ Institut für Mineralogie, Leibniz Universität Hannover, \\ Callinstraße 3, Hannover, Germany. \\ ${ }^{2}$ University of Tübingen, Tübingen, Germany. \\ ${ }^{3}$ Max Planck Institute for Chemistry, Climate Geochemistry \\ Department, Mainz, Germany. \\ ${ }^{4}$ University of Western Australia, Perth, Australia. \\ ${ }^{5}$ University of Wollongong, Wollongong, Australia. \\ *a.martin@mineralogie.uni-hannover.de
}

Archean microbial carbonates represent some of the earliest evidence for life on Earth. Trace elements incorporated into the Ca-carbonate matrix are valuable geochemical archives that provide information on the redox state of early waterbodies and potential diagenesis. Here we analysed the trace element composition of a range of modern and Archean microbial carbonates by fs-LA-ICPMS. Modern to Holocene samples include microbialites from Hamelin Pool, Shark Bay in Western Australia (hypersaline marine), Lake Baghdad, Rottnest Island in Western Australia (hypersaline lacustrine), and Lake Chew Bahir, Ethiopia (volcanic lacustrine). In addition, we sampled stromatolite limestones from the $2.72 \mathrm{Ga}$ Tumbiana Formation.

In modern and ancient samples, all elements except $\mathrm{Sr}$ were correlated with Th with $\mathrm{R}^{2}$ values ranging from 0.67 0.92, which is attributed to detrital input. Principal Components Analyses (PCA) suggest that although the primary mode of enrichment in Ca-carbonates is detrital contimation, there is a secondary enrichment of certain redoxsensitive metals. Moreover, different elements were enriched in different samples, e.g hypersaline lacustrine microbialites were enriched in $\mathrm{U}, \mathrm{Ni}, \mathrm{Co}, \mathrm{Mo}, \mathrm{Fe}, \mathrm{V}, \mathrm{Mn}$ but volcanic lacustrine microbialites were enriched in $\mathrm{Mn}, \mathrm{La}$, and $\mathrm{Ni}$, with minor enrichments in Co and V. Similar to modern samples, the Archean stromatilitic limestone was also enriched in $\mathrm{Fe}, \mathrm{Ni}$, and $\mathrm{Co}$ (with minor enrichments in $\mathrm{V}$ ); however, unlike modern samples, these redox-sensitive elements were inversely correlated with $\mathrm{Mn}, \mathrm{La}$ and $\mathrm{Ce}$. This inverse correlation may reflect the fundamentally different redox conditions in which the Tumbiana Formation formed. The shared enrichment of $\mathrm{Fe}, \mathrm{Ni}$, and $\mathrm{Co}$ in modern and ancient microbial may serve as an indicator for the biogenicity of ancient carbonates. 